\title{
Naar betere diabeteszorg tijdens de ramadan
}

\author{
Siham Bouchareb
}

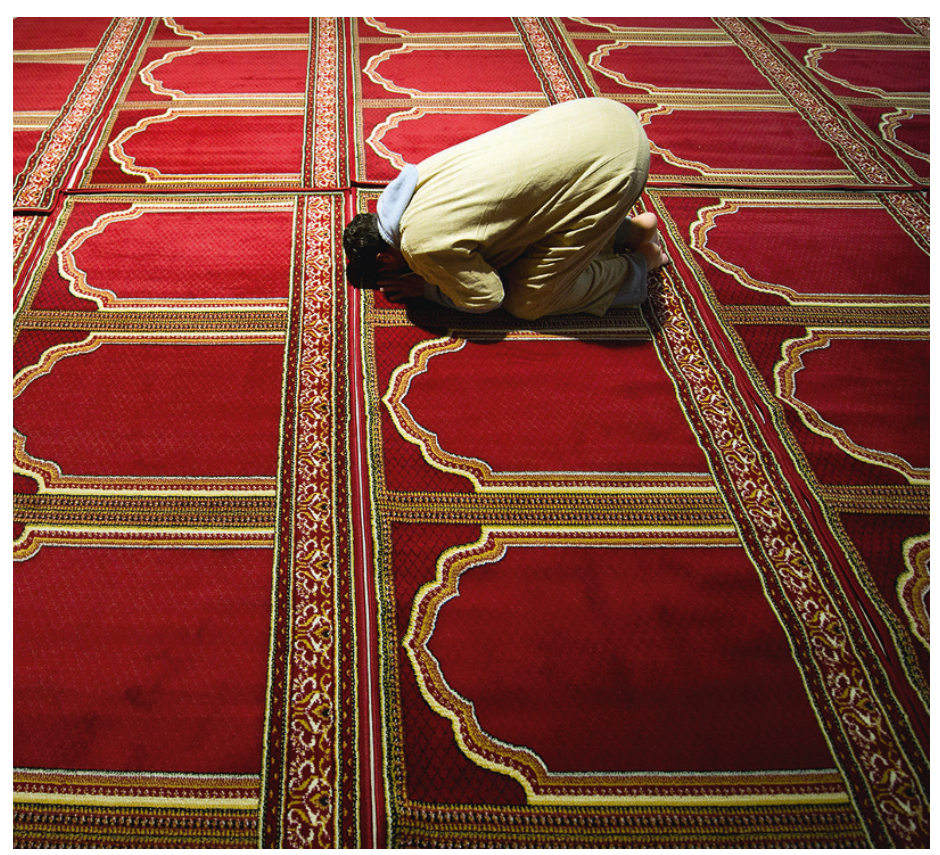

De ramadan kan gevaarlijk zijn voor diabetespatiënten.

Foto: anpfoto

Huisartsen en praktijkondersteuners hebben jaarlijks te maken met diabetespatiënten die graag willen vasten tijdens de ramadan, vaak tegen medisch advies in. Het is onduidelijk wat de omvang is van de glykemische ontregelingen door het vasten in Nederland, maar uit internationaal onderzoek blijkt dat de kans op acute complicaties tijdens de ramadan sterk is toegenomen. Om de diabeteszorg tijdens de ramadan te verbeteren, hebben Amsterdamse onderzoekers een specifiek project opgezet.

Het doel van dit project is om een cultuursensitief programma te ontwikkelen en een regionaal samenwerkingsverband op te zetten. Diabetespatiënten worden binnen hun eigen culturele setting benaderd, met een gelijkluidende boodschap van zowel zorgverleners als imams. De primaire uitkomstmaten zijn hoe de implementatie van het programma verloopt en hoe deze op grotere schaal kan worden toegepast. Voor de secundaire uitkomstmaat analyseren de onderzoekers het effect van het programma op onder andere de glykemische waarden en antropometrische parameters.

Internationaal onderzoek toonde al eerder aan dat de ramadan gevaarlijk kan zijn voor diabetespatiënten. ${ }^{1}$ De Nederlandse Diabetes Federatie (NDF) maakte daarom een handleiding om zorgverleners handvaten te bieden voor de begeleiding van diabetespatiënten tijdens de ramadan. ${ }^{2}$ Desondanks blijft diabeteszorg in die periode vaak lastig. Dat blijkt ook uit een recent focusgroeponderzoek bij praktijkondersteuners en patiënten in Amsterdam. De praktijkondersteuners hebben het idee dat zij van alle problemen alleen het topje van de ijsberg zien. De patiënten zeggen behoefte te hebben aan meer informatie over diabetes en willen graag adviezen over hoe zij zo 'veilig' mogelijk aan de ramadan kunnen deelnemen. In 2011 werd geregistreerd dat de huidige diabetesprogramma's nog onvoldoende in staat zijn om de sociale en culturele barrières te doorbreken. ${ }^{3}$

In het Verenigd Koninkrijk is een niet-gerandomiseerd onderzoek gedaan naar het effect van een educatieprogramma over de ramadan. ${ }^{4}$ Daaruit bleek dat patiënten die het programma hadden gevolgd minder hypoglykemieën hadden tijdens de ramadan, minder gewichtstoename en gedurende het gehele jaar stabielere HbAlc-waarden dan patiënten die het programma niet hadden gevolgd.

Dit nieuwe onderzoek moet uitwijzen hoe we de diabeteszorg tijdens de ramadan in Nederland het best kunnen organiseren. Het onderzoek loopt tot september 2019. -

\section{LITERATUUR}

1. Salti I, Bénard E, Detournay B, Bianchi-Biscay M, Le Brigand $\mathrm{C}$, Voinet $\mathrm{C}$, et al. A population-based study of diabetes and its characteristics during the fasting month of Ramadan in 13 countries: results of the epidemiology of diabetes and Ramadan 1422/2001 (EPIDIAR) study. Diabetes Care 2004;27:2306-11. https://doi.org/10.2337/diacare.

2. NDF. Diabetes en ramadan. Adviezen voor behandelaars. NDF/ JvO 2018.

3. Jansen YJFM, Uitewaal PJM, Wijsman-Grootendorst A, Geelhoed-Duijvestijn PHLM. Sociale en culturele problemen bij het opvolgen van leefstijladviezen door allochtone diabetici. Ned Tijdschr Geneeskd 2011;155:A3117.

4. Bravis V, Hui E, Salih S, Mehar S, Hassanein M, Devendra D. Ramadan education and awareness in diabetes (READ) programme for muslims with type 2 diabetes who fast during ramadan. Diabet Med 2010;27:327-31. DOI:10.1111/j.1464-5491.2010.02948.

Bouchareb S. Naar betere diabeteszorg tijdens de ramadan. Huisarts Wet 2018;61[10]:62. Amsterdam UMC, Vrije Universiteit Amsterdam, afdeling Huisartsgeneeskunde en Ouderengeneeskunde: S. Bouchareb, aiotho, s.bouchareb@ vumc.nl.

Dit is een bijdrage in de rubriek Lopend onderzoek, relevant voor de eerste lijn, geschreven door een promovendus. 